\title{
Observations of "coarse" root development in young trees of nine exotic species from a New Zealand plot trial
}

\author{
Chris J. Phillips ${ }^{1 *}$, Michael Marden² and Suzanne M. Lambie ${ }^{3}$
}

\begin{abstract}
Background: Forests and wide-spaced trees are used widely in New Zealand to control erosion from shallow landslides. Species that offer similar or better levels of protection to those currently used are sought to meet future needs. Determining what plants to use and when they become effective is important for developing guidelines and policy for land management. This study aimed to obtain data on above- and below-ground plant growth for young exotic tree species considered potential candidates for future 'erosion control forests'.

Methods: The above- and below-ground growth of nine exotic tree species was assessed annually for 3 years from planting in a randomised block field trial. Whole trees were excavated and destructively sampled and several below-ground metrics (total root length of all roots $>1 \mathrm{~mm}$ in diameter, lateral root spread, total root biomass) assessed.

Results: Differences between species for most metrics at the time of planting carried through to Year 3. The best performing species across most metrics was alder, followed by blackwood, cherry, and cypress. Allometric models relating total root length and below-ground biomass to root collar diameter were established.

Conclusion: Top performers with regard to root metrics were alder, cherry, and cypress followed by blackwood, radiata, and redwood. Root information contributes to improving our understanding of how and when, and at what planting density, plants become effective for controlling erosion in New Zealand.
\end{abstract}

Keywords: Above-ground biomass; Below-ground biomass; Root development; Shallow landslide erosion; Soil conservation

\section{Background}

The New Zealand plantation forest estate is dominated by Pinus radiata D.Don (radiata pine) with this one species occupying $90 \%$ of the plantation estate (New Zealand Forest Owners Association 2013). Outside plantation forests, Populus and Salix species (often planted as single trees or wide-spaced groups of trees) are the most common exotic species and are used extensively for soil conservation and river control across New Zealand (Douglas et al. 2011). In spite of the widespread use of exotic species in New Zealand's managed (i.e. non-conservation) lands, there are a number of factors that are likely to shape future New Zealand production

\footnotetext{
* Correspondence: phillipsc@landcareresearch.co.nz

'Landcare Research, PO Box 69040, Lincoln 7640, New Zealand

Full list of author information is available at the end of the article
}

forests. These include: the sustainability of the New Zealand forest industry, in particular its resilience in the face of climate change (Ministry of Agriculture and Forestry 2008); the increasing demand for land for dairying (New Zealand Forest Owners Association 2013); and a move towards species diversification to reduce potential threats from disease or insect damage. There is also likely to be an increasing focus on non-wood production benefits (values or ecosystem services) from forests (plantations or natural) in the future (O'Loughlin 2005; Smaill et al. 2014). Of those services (amenity value, bioenergy production, carbon capture, biodiversity, and erosion control), the use of forests for controlling or reducing the impacts of rain events (storms) on erosionsusceptible land has continuing importance for many regions of New Zealand. Forests, together with wide-spaced 
erosion control or soil conservation trees, also continue to be actively promoted as erosion mitigation tools integral to sustainable land management in many regions (Ministry of Agriculture and Forestry 2010).

Forests are generally recognised to provide protection from hydrogeomorphic hazards such as floods, landslides, debris flows, snow avalanches and rockfalls (Sidle et al. 1985; Brang et al. 2001; Sidle and Ochiai 2006; Blaschke et al. 2008). An extensive literature exists on the benefits of trees, shrubs and grasses for reinforcing soils to control or reduce both surficial and shallow mass-movement erosion (e.g. Phillips et al. 1990; Marden \& Rowan 1993; Phillips \& Marden 2005; Stokes et al. 2008, 2009). Root reinforcement is now recognised as an important factor affecting several hydro-mechanical processes that give rise to the hazards mentioned above (Schwarz et al. 2013). However, while it is acknowledged that vegetation imparts additional strength to soil via its reinforcing root network, the amount of information recording the development and growth of a species' root system is sparse, particularly for larger trees (e.g. Mao et al. 2013). This paucity of quantitative data is largely because obtaining belowground plant information is difficult, time-consuming, and expensive. Thus data sets for individual species over time are not abundant, the sample sizes per age class where these data exist are generally small or limited to one age class only (e.g. Danjon et al. 1999; Mulatya et al. 2002; Docker and Hubble 2008), and thus the statistical power of many relationships are generally limited by small sample sizes. Nevertheless, such data, be they from replicated trials or from single tree observations, are necessary to both improve our general understanding of a species' performance and to develop, calibrate, and validate either conceptual or quantitative models that incorporate root information for use in predicting the effects of vegetation on slope stability (Ekanayake \& Phillips 1999, 2002; Schwarz et al. 2010; Phillips et al. 2011; Stokes et al. 2014) and hence the effectiveness of revegetation policies (Phillips et al. 2013b).

The on-site benefits of planted radiata pine (Pinus radiata D.Don) forests, on-farm plantings of Populus species, and some New Zealand native species for controlling erosion are relatively well understood even though the amount of quantitative data on their root system development is small (e.g. Phillips \& Watson 1994; Phillips et al. 2013a, 2014). These benefits include a reduction in shallow landsliding (Marden \& Rowan 1993; Phillips and Marden 2005; Douglas et al. 2011; Basher 2013), reduced rates of earthflow movement (O'Loughlin \& Zhang 1986; Marden et al. 2008), reduced gully erosion (Parkner et al. 2007; Marden et al. 2012) and the retention of soil. Depending on factors such as geology, species, tree density, and slope steepness, plantation forests can be effective in controlling erosion as soon as 5-8 years after planting (O'Loughlin \& Zhang 1986; Phillips et al. 2012).

In recent years, there has been increasing interest among some land owners and forestry stakeholders that species other than Pinus radiata might be better suited to the wider provision of ecosystem services (e.g. Trotter et al. 2005). However, in a recent survey of foresters and their stakeholders, strong opinions were revealed regarding the relative performance and suitability of various tree species to deliver those ecosystem services from New Zealand's plantation forests (Smaill et al. 2014). This study demonstrated that many of the opinions held by stakeholders were inaccurate when compared with available data from growth, physiological and ecological studies (Smaill et al. 2014). These data where they exist, are largely from studies of above-ground growth performance but our understanding of many species' development of below-ground traits required for root reinforcement and erosion control is severely lacking both in New Zealand and more generally internationally (e.g. Stokes et al. 2009; Phillips et al. 2011). However, although limited in many cases, data on root spread, root depth, and total root length, can and have been used to compare, at least in a general sense, the performance of a species in terms of effectiveness for erosion control (Phillips et al. 2011; Stokes et al. 2009; Phillips et al. 2013a, 2014). These data are required to underpin needs identified by both researchers and practitioners alike concerning the ecological mitigation of hillslope instability (Stokes et al. 2014).

To address this lack of basic below-ground information, a field plot trial was established to provide early growth data and observations on the "coarse" root development of nine exotic tree species (Table 1). Species selection was not based on any assessment using rigorous criteria. Rather, the species selected are common, are in widespread use by farmers and farm foresters across New Zealand, and were readily obtainable from New Zealand nurseries. Researcher consensus narrowed potential candidates down to the final nine. Data were collected in such a way that they could be directly compared with existing data (mostly for radiata pine).

This paper reports on the observations and results of that trial, compares results with other species for which below-ground New Zealand root data exist, and then briefly discusses the implications for their use in erosion control. Our focus for the latter is on the use of trees to mitigate shallow landsliding (i.e. shallow landslides (soil slips), debris avalanches, debris flows, earthflows) rather than on surface erosion (slopewash, dry ravelling, etc.) because the former are the main erosion processes of concern in New Zealand's hill country and steeplands (Crozier 2005; Basher 2013). 
Table 1 Seed sources and nursery treatment

\begin{tabular}{|c|c|c|c|c|}
\hline Species & Common name ${ }^{a}$ & Source and treatment & $\begin{array}{l}\text { Physiological age at } \\
\text { planting (years) }\end{array}$ & $\begin{array}{l}\text { Mean seedling height } \\
\text { at planting }(\mathrm{m})\end{array}$ \\
\hline Quercus robur & Oak & $\begin{array}{l}\text { Seedlings sourced from a local tree where seed had } \\
\text { fallen and germinated in leaf litter/bark/garden soil. } \\
2009 \text { germination. }\end{array}$ & 2 & 0.27 \\
\hline Eucalyptus fastigata & Eucalypt & $\begin{array}{l}\text { Direct open-ground-sown into commercial nursery } \\
\text { bed, October } 2009 .\end{array}$ & 1 & 0.36 \\
\hline Pseudotsuga menziesii & Douglas-fir & $\begin{array}{l}\text { Direct open-ground-sown into commercial nursery } \\
\text { bed, October } 2009 .\end{array}$ & 1 & 0.15 \\
\hline Sequoia sempervirens & Redwood & $\begin{array}{l}\text { Direct open-ground-sown into commercial nursery } \\
\text { bed, October } 2009 .\end{array}$ & 1 & 0.37 \\
\hline Prunus serrulatus & Cherry & $\begin{array}{l}\text { Transplanted from under a local tree where the } \\
\text { seed had fallen and germinated in the leaf litter. } \\
2009 \text { germination. }\end{array}$ & 2 & 0.79 \\
\hline Acacia melanoxylon & Blackwood & $\begin{array}{l}\text { Direct open-ground-sown into commercial nursery } \\
\text { bed, October } 2009 .\end{array}$ & 1 & 0.72 \\
\hline Alnus rubra & Alder & $\begin{array}{l}\text { Direct open-ground-sown into commercial nursery } \\
\text { bed, October } 2009 .\end{array}$ & 1 & 0.83 \\
\hline Cupressus lusitanica & Cypress & $\begin{array}{l}\text { Direct open-ground-sown into commercial nursery } \\
\text { bed, October } 2009 .\end{array}$ & 1 & 0.42 \\
\hline Pinus radiata & Radiata & $\begin{array}{l}\text { GF } 19 \text { improved seed. Direct open-ground-sown } \\
\text { into commercial nursery bed, October } 2009 .\end{array}$ & 1 & 0.43 \\
\hline
\end{tabular}

${ }^{\mathrm{a}}$ Common name used in this paper

\section{Methods}

A randomised field plant trial with three "replicates" in two blocks of each of nine species grown over 3 years (81 plants) was established in July 2010 near Gisborne, North Island, New Zealand. Species names, common names, and nursery treatments are listed in Table 1. The trial was established on the same site as earlier trials that examined root growth of both native and exotic species (Marden et al. 2005; Phillips et al. 2014). The field site is located on a low-lying, even-surfaced near-flat alluvial terrace adjacent to the Taraheru River (Fig. 1). The soil is free-draining, Te Hapara soil (Typic Sandy Brown; Hewitt 2010) and may require irrigation in summer to ensure plant survival. The soil has no physical or chemical impediments to root development to at least about $1.2 \mathrm{~m}$ depth, other than a variable-depth water table. Across the site, the soil appeared to be relatively uniform, with a sandy loamy texture. The topsoil was homogenised through a history of cultivation, with no obvious development of tillage pans, though soil density appeared to be greater at depths beyond $0.5 \mathrm{~m}$. The climate is also favourable to tree growth, being warm temperate with average winter low temperatures of about $5{ }^{\circ} \mathrm{C}$ and average summer highs of $25{ }^{\circ} \mathrm{C}$ and about $1000 \mathrm{~mm}$ annual rainfall. The trial plot $(50 \times 20 \mathrm{~m})$ was fenced to exclude grazing animals and tilled before plants were established in two side-by-side blocks at $2.5 \mathrm{~m}$ spacing according to the trial design.

Seedlings were either grown in-house from locally collected seed or supplied by a commercial/research nursery in Rotorua (Scion pers. comm.) (Table 1) and were typical of what would be supplied to farmers or foresters (Fig. 2). Thus, the physiological age of each species was not consistent and results are presented as "years since planting" (i.e. Year 0 being material as supplied from the nursery, Year 1 after one year's growth in the trial plot, etc.) and species like alder, cherry, and oak were considerably larger at time of planting than radiata and Douglas-fir (Table 1; Figs. 2 \& 3). As part of commercial nursery practice, seedling roots were conditioned/undercut (i.e. root pruned). To help ensure the survival of seedlings in the trial plot, weed mat was laid to reduce competition from weeds, trickle irrigation was installed as a precaution against extended dry periods (not required), and wire cages were placed over plants initially to limit browsing damage by hares (Lepus europaeus) and pūkeko (Porphyrio melanotus), a native bird known to pull out small plants.

Measurement methods of both above- and belowground metrics followed well-established procedures used in earlier studies (Watson et al. 1999; Czernin \& Phillips 2005; Marden et al. 2005; Phillips et al. 2014). Various metrics or traits have also been used to help assess species performance in terms of erosion-control effectiveness (Stokes et al. 2009; Phillips et al. 2011). In this study, above-ground metrics included tree height, canopy spread (i.e. canopy diameter), root-collar diameter (RCD - measured at ground level) and diameter at breast height where applicable (DBH - measured $1.4 \mathrm{~m}$ above ground level). Above-ground biomass was measured 


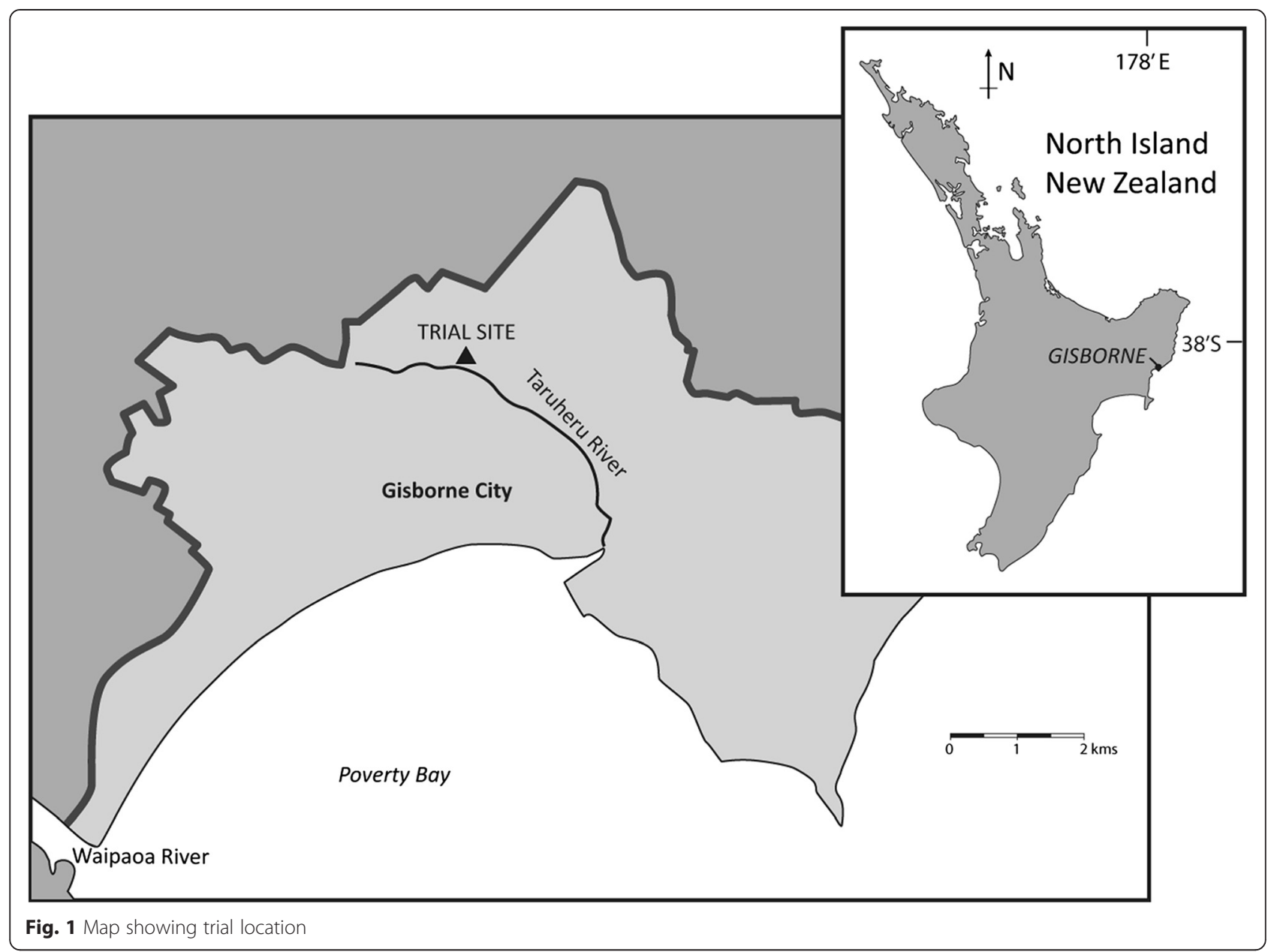

separately for foliage, branches and stem. Foliage was not present at the time of extractions in the deciduous species. Maximum depth, spread of lateral roots, total root length of all roots $>1 \mathrm{~mm}$ in diameter, root diameter size class distribution, and total below-ground biomass were assessed. Lateral root spread together with canopy spread, was taken as the average of the maximum diameters measured by tape measure in two directions at right angles, approximating a N-S and E-W line. The long axis of the field plot was oriented approximately N-S. Plants were extracted and measured each year about the anniversary of the planting date (Year 1, Year 2, and Year 3). Trees of each species were extracted in July 2011 after 1 year in the ground. Year-2 extractions were conducted in late June and early July 2012 after 2 years in the ground. Year- 3 and final extractions took place in late May and early June 2013.

Root systems were extracted using an air spade (an ultrasonic high pressure device to disaggregate and remove soil from around the roots) or by hand, particularly in the first year (s) when plants were small. Once removed from the ground, the plants were destructively sampled to determine the parameters outlined above, all of which could then be related to over bark root-collar diameter (i.e. groundline diameter or basal diameter at root collar) and over bark diameter at breast height $(1.35 \mathrm{~m})$ (when plants grew tall enough). Ten additional sample trees of each species were also destructively sampled at the time of planting (Year 0, i.e. seedlings as delivered from the nursery, see Fig. 2).

The complete root system of each plant was photographed before the plant was destructively partitioned into $0.5 \mathrm{~m}$ radial and depth segments (see Czernin \& Phillips 2005). Roots within each radial segment were further partitioned into diameter size-classes $(<1 \mathrm{~mm}$ (fibrous), $1-2,>2-5,>5-10,>10-20,>20-50,>50-100$ $\mathrm{mm}$ ) (Watson \& O'Loughlin 1990). Over-bark root diameters of all roots were measured with digital callipers. For each radial segment, total root length for each diameter size-class was determined by placing roots end to end (excluding fibrous roots $<1 \mathrm{~mm}$ in diameter). Roots were then oven-dried for biomass determination. Both above- and below-ground components were oven-dried at $80^{\circ} \mathrm{C}$ for $24 \mathrm{~h}$ then weighed to the nearest $0.1 \mathrm{~g}$. 


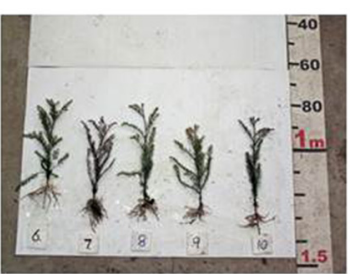

Redwood

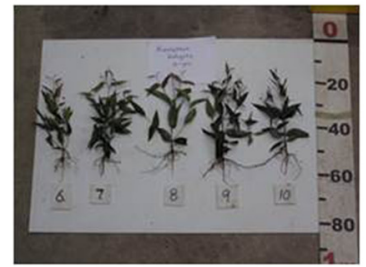

Eucalypt

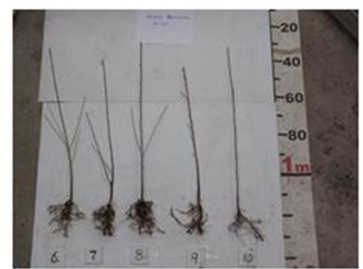

Cherry

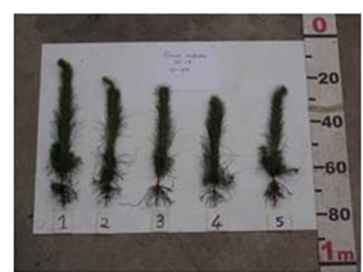

Radiata

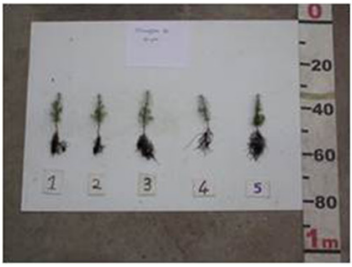

Douglas-fir

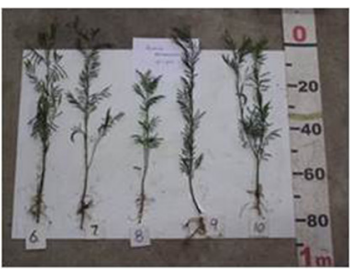

Blackwood

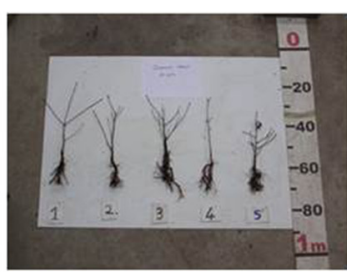

Oak

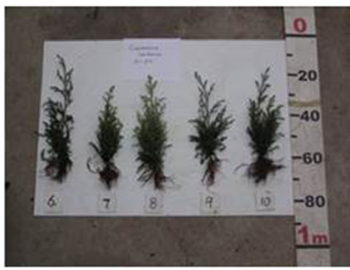

Cypress

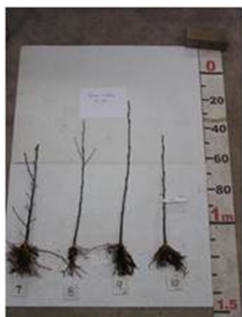

Alder

Fig. 2 Photographs of seedlings at time of planting to illustrate size and form differences. Not to scale

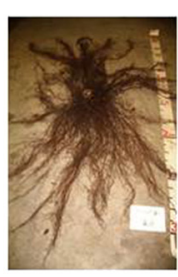

Redwood

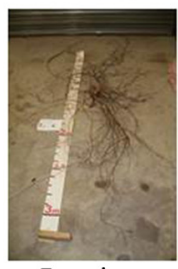

Eucalypt

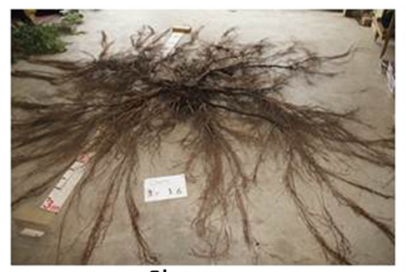

Cherry

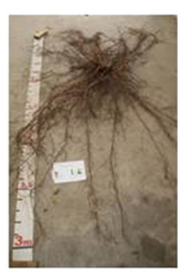

Radiata

\begin{tabular}{|l|}
\hline $\begin{array}{c}\text { No } 3 \text { year } \\
\text { old } \\
\text { survivors }\end{array}$ \\
\hline Douglas-fir
\end{tabular}

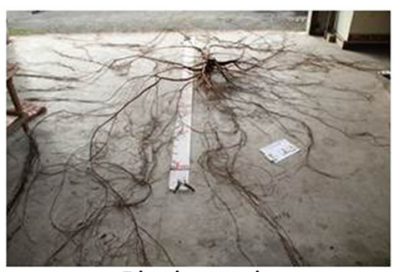

Blackwood

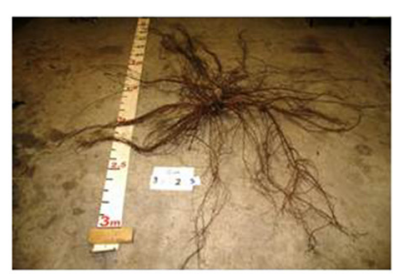

Oak

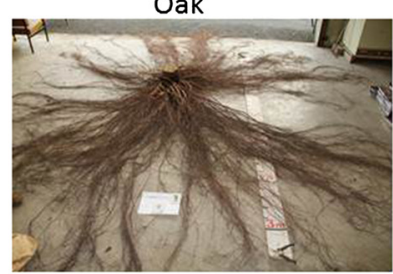

Cypress

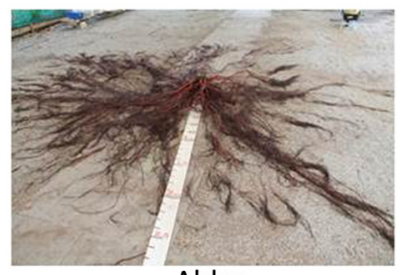

Alder

Fig. 3 Photographs at Year 3 of representative root systems illustrating differences in root architecture. Not to scale. Tape is $3 \mathrm{~m}$ 
Though three alders survived through to Year 3, one tree only was randomly selected for full excavation and processing as resources were insufficient to deal with the remaining two due to their large size and the time to extract and process them (on average more than 3-4 days per tree for a team of four people).

While it is acknowledged that obtaining powerful statistical relationships for many root parameters due to small sample sizes is difficult, it is possible to move beyond simple empirical observations where sufficient sample numbers exist. Differences in growth characteristics among tree species within each year of the trial were determined using $2 \times 2$ factorial analysis of variance (ANOVA) blocked by planting blocks (GenStat 12; VSN International, Hemel Hempstead, UK). Analysis of differences within each tree species over the course of the trial was also undertaken using ANOVA. Analyses were considered significant if $P<0.05$. Some of the data were transformed $(\log 10)$ for ANOVA following residual normality analysis. Nevertheless, all results are presented as untransformed means and standard errors of the means, unless otherwise stated.

\section{Results}

\section{Survival and general description of root systems}

There were minor losses of blackwood, redwood and eucalypt soon after planting due, we suspect, to browsing by animals (rabbits - Oryctolagus cuniculus; hares; and pūkeko) or from the water table rising into the rooting zone over the winter months and causing subsoil waterlogging. Douglas-fir showed initial signs of stress due to a post-planting 'wet period' but losses at Year 1 were not severe enough to compromise the objectives of the trial. However, at Year 2, all Douglas-fir had died. Other trees (5 of 24), also sustained 'damage' in the second year of the trial, exhibiting broken branches or toppling likely caused by wind. At Year 3, 19 of the 27 trees marked for extraction had survived. Of these, blackwood, alder and radiata had three surviving replicates with the other species having only two each.

The nine trialled species were a mix of evergreen and deciduous trees and exhibited a range of tree form. Canopy shape and density were variable with some species having a bushy shrub-like appearance and others more streamlined canopies and forms. In a similar manner, the below-ground appearance of the root systems was also variable. Several species had low root density (i.e. low numbers of roots per $\mathrm{m}^{2}$ of soil) and elongated "spidery" lateral roots with few small side branches (low root branching order) (blackwood, eucalypt, oak) (Fig. 3). Alder and cherry had dense branching lateral root systems with high root numbers (high root density and high root order) while redwood and cypress had similar dense root systems, but many fine long branching roots.
Radiata had long laterals with limited branching order, similar to blackwood but with a greater number of short branch roots on the main laterals. Alder, redwood and cypress roots were reddish in colour, radiata orange, blackwood and oak pale brown, cherry pale brown to white, and eucalypt dark brown.

\section{Growth performance parameters}

Visual and quantitative differences among species for most metrics at the time of planting carried through to Year 3. At both 2 and 3 years from planting, the best performing species across most metrics was alder, followed by blackwood, cherry, and cypress (Tables 2, 3, 4 \& 5, Figs. 3, 4, 5, 6 \& 7). Alder was the tallest tree at Year 3 (6.4 $\mathrm{m}$ maximum tree height) with cypress $(4.9 \mathrm{~m})$ and eucalypt $(4.0 \mathrm{~m})$ also performing well (Fig. 4).

Largest root spread was in a Year-3 blackwood at 10.3 $\mathrm{m}$ with one Year-2 blackwood having $9.0 \mathrm{~m}$ root spread. The Year-3 alder had a root spread of $7.7 \mathrm{~m}$, though one Year 2 tree had a spread of $8.5 \mathrm{~m}$. Blackwood had a mean root spread of $6.9 \mathrm{~m}$, eucalypt $4.5 \mathrm{~m}$, and cherry was $3.2 \mathrm{~m}$. Overall, blackwood and alder had significantly greater root spread than the other species at Year $2(P<0.001)$ although there was no statistically significant difference between any of the tree species in Year 3 due to large variation in growth within a particular species, even though visibly the Year-3 root systems looked larger than those in year 2 (Fig. 5).

Root depth was variable (total mean range at Year 2 was $0.18-0.45 \mathrm{~m}$ ) among species and trends established in Year 1 continued through to Year 3. Alder roots were significantly deeper than the other species in Year 3, and roots did not go deeper than about $0.5 \mathrm{~m}$ in any year of the trial.

Mean above-ground biomass (AGB) of Year-3 cypress was $29 \mathrm{~kg}$ with the largest of the two trees having $46 \mathrm{~kg}$ above- and $8 \mathrm{~kg}$ below-ground (including root bole or stump). Alder was the next best performing species in mean total biomass and had the greatest below-ground biomass (BGB) of all species at both Year 2 and 3, closely followed by cherry. However, statistically there was no difference between species in both above- and below-ground biomass at Year 3, largely because of the wide range in values for cypress and cherry (big error bars) $(P=0.130$ for AGB and $P=0.365$ for BGB) (Fig. 6).

Alder had the greatest total root length (all roots $>1$ $\mathrm{mm}$ in diameter) of the trial species at Year 2, ranging from 1347 to $2262 \mathrm{~m}$. A Year-2 alder had the greatest total root length of all trees excavated at $2262 \mathrm{~m}$, considerably more than the random Year-3 alder chosen for excavation $(1268 \mathrm{~m})$. At Year 3, the excavated alder had a significantly greater root length than the other species $(P=0.006)$ but was not significantly different from cypress (Fig. 7). 
Table 2 Attributes for 0-year-old trialled species

\begin{tabular}{|c|c|c|c|c|c|c|c|c|c|}
\hline Attribute & Oak & Eucalypt & Douglas-fir & Redwood & Cherry & Blackwood & Alder & Cypress & Radiata \\
\hline Trees sampled & 10 & 10 & 10 & 10 & 10 & 10 & 10 & 10 & 10 \\
\hline Tree height (m) & $0.27(0.02)$ & $0.36(0.01)$ & $0.15(0.00)$ & $0.37(0.01)$ & $0.79(0.02)$ & $0.72(0.03)$ & $0.83(0.04)$ & $0.42(0.03)$ & $0.43(0.03)$ \\
\hline Canopy spread (m) & $0.14(0.02)$ & $0.24(0.01)$ & $0.06(0.00)$ & $0.23(0.01)$ & $0.13(0.02)$ & $0.19(0.02)$ & $0.11(0.03)$ & $0.19(0.01)$ & $0.15(0.01)$ \\
\hline $\mathrm{DBH}^{\mathrm{a}}(\mathrm{mm})$ & - & - & - & - & - & - & - & - & - \\
\hline $\mathrm{RCD}^{\mathrm{b}}(\mathrm{mm})$ & $9(0.6)$ & $6(0.3)$ & $3(0.7)$ & $5(0.2)$ & $9(0.5)$ & $8(0.5)$ & $13(0.6)$ & $8(0.3)$ & $7(0.3)$ \\
\hline Max. root diameter $(\mathrm{m})$ & $0.12(0.01)$ & $0.17(0.02)$ & $0.09(0.00)$ & $0.16(0.01)$ & $0.22(0.01)$ & $0.15(0.02)$ & $0.39(0.05)$ & $0.21(0.02)$ & $0.14(0.01)$ \\
\hline Max. root depth (m) & $0.15(0.001)$ & $0.12(0.001)$ & $0.12(0.001)$ & $0.12(0.001)$ & $0.17(0.001)$ & $0.13(0.001)$ & $0.18(0.001)$ & $0.13(0.001)$ & $0.10(0.001)$ \\
\hline Total AGBC (g) & $4(0.4)$ & $6(0.7)$ & $1(0.1)$ & $5(0.4)$ & $11(0.8)$ & $13(1.9)$ & $18(2.5)$ & $14(1.0)$ & $13(1.0)$ \\
\hline Total BGB ${ }^{d}(g)$ & $7(1.0)$ & $1(0.1)$ & $1(0.1)$ & $1(0.3)$ & $11(1.1)$ & $3(0.5)$ & $20(3.0)$ & $3(0.3)$ & $2(0.2)$ \\
\hline Total root mass ${ }^{\mathrm{e}}(\mathrm{g})$ & $7(1.0)$ & $1(0.1)$ & $1(0.1)$ & $1(0.3)$ & $11(1.1)$ & $3(0.5)$ & $20(3.0)$ & $3(0.3)$ & $2(0.2)$ \\
\hline Total root length $>1 \mathrm{~mm}(\mathrm{~m})$ & $0.64(0.11)$ & $0.59(0.08)$ & $0.29(0.05)$ & $0.71(0.08)$ & $1.63(0.19)$ & $0.53(0.14)$ & $4.11(0.43)$ & $1.34(0.18)$ & $0.77(0.11)$ \\
\hline
\end{tabular}

Data are presented as means, numbers in brackets are standard error of the mean. ${ }^{a}$ diameter at breast height, ${ }^{b}$ root collar diameter, ${ }^{c}$ total above-ground biomass, ${ }^{d}$ total below-ground biomass including stump/root bole, ${ }^{e}$ total root mass excluding the stump/root bole

The distribution of total root length by root diameter class about the stem shows two distinct patterns (Table 6). Firstly, oak, redwood and radiata have greater than $50 \%$ of their total root length within $1 \mathrm{~m}$ of the stem, and show a rapid linear decline in total root length with radial distance. The remaining species, apart from eucalypt, have less than $40 \%$ of their total root length within $1 \mathrm{~m}$ of the stem, and show a pattern of increasing total root length with distance from the stem to a maximum at about $1.5-2.0 \mathrm{~m}$ and then declining (Fig. 8). Greatest total root length was found in the finest root diameter class $(1-2 \mathrm{~mm})$ independent of radial distance from the stem, except for alder at $3.5 \mathrm{~m}$ distance from the stem where there was more total root length in the $>2-5 \mathrm{~mm}$ diameter size class than the 1-2 $\mathrm{mm}$ class (Table 6). Total root length declined as roots increased in diameter and the thickest roots were found close to the stem.
In terms of growth differences within species between years, for most trialled species and for most metrics, there were significant differences between years. The metrics that tended to show no difference were root length and root:shoot ratio for most species although alder and blackwood were significantly different between Year 0,1 and 2 but Year 2 and 3 were the same $(P<0.001)$.

For individual metrics, Year- 0 data tended to show the most differences between species, although for each metric, different species grouped differently. Across all metrics, alder by being larger at the time of planting tended to be the best, or in the group of best performers for each year.

\section{Allometric relationships}

Allometric relationships are used to predict tree growth on the basis of easy-to-measure aboveground parameters such as diameter at breast height

Table 3 Attributes for 1-year-old trialled species

\begin{tabular}{|c|c|c|c|c|c|c|c|c|c|}
\hline Attribute & Oak & Eucalypt & Douglas-fir & Redwood & Cherry & Blackwood & Alder & Cypress & Radiata \\
\hline Trees sampled & 3 & 3 & 1 & 3 & 3 & 3 & 3 & 3 & 3 \\
\hline Tree height (m) & $0.80(0.25)$ & $1.01(0.41)$ & 0.18 & $1.00(0.15)$ & $1.51(0.17)$ & $1.57(0.17)$ & $2.86(0.58)$ & $1.21(0.11)$ & $0.92(0.17)$ \\
\hline Canopy spread (m) & $0.56(0.02)$ & $0.61(0.28)$ & 0.05 & $0.81(0.08)$ & $0.55(0.25)$ & $0.55(0.05)$ & $0.97(0.50)$ & $0.54(0.03)$ & $0.37(0.15)$ \\
\hline $\mathrm{DBH}^{\mathrm{a}}(\mathrm{mm})$ & - & $4(N / A)$ & - & - & $8(N / A)$ & $5(N / A)$ & $20(4.7)$ & - & - \\
\hline $\mathrm{RCD}^{\mathrm{b}}(\mathrm{mm})$ & $21(1.2)$ & $24(10.2)$ & 6 & $24(0.4)$ & $27(0.7)$ & $25(1.4)$ & $49(5.6)$ & $24(2.0)$ & $19(2.9)$ \\
\hline Max. root diameter $(\mathrm{m})$ & $0.97(0.24)$ & $0.73(0.45)$ & 0.09 & $0.93(0.03)$ & $1.69(0.41)$ & $2.23(0.39)$ & $2.60(0.80)$ & $0.93(0.07)$ & $0.87(0.16)$ \\
\hline Max. root depth (m) & $0.32(0.02)$ & $0.11(0.01)$ & 0.09 & $0.22(0.04)$ & $0.21(0.02)$ & $0.27(0.03)$ & $0.28(0.02)$ & $0.20(0.02)$ & $0.17(0.03)$ \\
\hline Total $A_{G B}{ }^{C}(g)$ & $86(37)$ & $218(151)$ & 4 & $147(54)$ & $232(56)$ & $199(51)$ & $996(240)$ & $239(60)$ & $117(42)$ \\
\hline Total BGB ${ }^{\mathrm{d}}(\mathrm{g})$ & $71(21)$ & $28(19)$ & 1 & $37(11)$ & $197(43)$ & $57(10)$ & $731(201)$ & $39(12)$ & $18(5)$ \\
\hline Total root mass ${ }^{\mathrm{e}}(\mathrm{g})$ & $40(10)$ & $20(13)$ & 1 & $28(8)$ & $149(39)$ & $30(4)$ & $596(182)$ & $23(3)$ & $13(3)$ \\
\hline Total root length $>1 \mathrm{~mm}(\mathrm{~m})$ & $9.0(2.5)$ & $6.0(3.8)$ & 0.2 & $19.4(3.7)$ & $29.6(18.7)$ & $10.6(2.1)$ & $140(40.8)$ & $16(3.5)$ & $16(10)$ \\
\hline
\end{tabular}

Data are presented as means (with the exception of Douglas-fir), numbers in brackets are standard error of the mean. ${ }^{a}$ diameter at breast height, ${ }^{b}$ root collar diameter, ${ }^{c}$ total above -ground biomass, ${ }^{d}$ total below-ground biomass including stump/root bole, ${ }^{e}$ total root mass excluding the stump/root bole 
Table 4 Attributes for 2-year-old trialled species

\begin{tabular}{llllllllll}
\hline Attribute & Oak & Eucalypt & Douglas-fir & Redwood & Cherry & Blackwood & Alder & Cypress & Radiata \\
\hline Trees sampled & 3 & 3 & - & 3 & 3 & 3 & 3 & 3 & 3 \\
Tree height $(\mathrm{m})$ & $0.63(0.03)$ & $2.51(0.56)$ & - & $1.47(0.38)$ & $2.60(0.36)$ & $3.53(0.52)$ & $4.73(2.30)$ & $2.27(0.26)$ & $1.30(0.47)$ \\
Canopy spread $(\mathrm{m})$ & $0.39(0.12)$ & $1.43(0.36)$ & - & $1.05(0.34)$ & $1.08(0.17)$ & $1.63(0.29)$ & $3.73(0.19)$ & $1.67(0.18)$ & $0.38(0.14)$ \\
$\mathrm{DBH}^{\mathrm{a}}(\mathrm{mm})$ & - & $21(3.3)$ & - & $8(1.4)$ & $19(5.0)$ & $39(7.5)$ & $60(8.3)$ & $16(0.1)$ & $19(\mathrm{~N} / \mathrm{A})$ \\
$\mathrm{RCD}^{\mathrm{b}}(\mathrm{mm})$ & $19(1.4)$ & $73(15.9)$ & - & $45(13.8)$ & $63(10.9)$ & $71(9.0)$ & $144(11.7)$ & $43(0.1)$ & $29(10.6)$ \\
Max. root diameter $(\mathrm{m})$ & $0.57(0.06)$ & $2.10(0.20)$ & - & $1.32(0.34)$ & $3.33(0.54)$ & $6.33(1.45)$ & $6.70(0.99)$ & $3.00(0.25)$ & $1.10(0.44)$ \\
Max. root depth $(\mathrm{m})$ & $0.45(0.03)$ & $0.18(0.03)$ & - & $0.20(0.03)$ & $0.22(0.01)$ & $0.39(0.04)$ & $0.42(0.04)$ & $0.21(0.01)$ & $0.23(0.12)$ \\
Total AGB $(\mathrm{g})$ & $46(17)$ & $2454(1032)$ & - & $669(313)$ & $2180(830)$ & $4347(1146)$ & $11106(377)$ & $3833(759)$ & $301(171)$ \\
Total BGB ${ }^{d}(\mathrm{~g})$ & $65(28)$ & $523(250)$ & - & $138(65)$ & $2088(910)$ & $1675(1403)$ & $8438(1212)$ & $1037(582)$ & $52(22)$ \\
Total root mass $(\mathrm{g})$ & $49(22)$ & $350(166)$ & - & $81(40)$ & $1699(748)$ & $1275(244)$ & $7091(1279)$ & $801(510)$ & $24(10)$ \\
Total root length $>1 \mathrm{~mm}(\mathrm{~m})$ & $6.0(1.2)$ & $43.4(18.1)$ & - & $33.3(16.2)$ & $180.9(86.6)$ & $119.5(21.9)$ & $1508.2(397.2)$ & $147(31.3)$ & $11.3(4.4)$ \\
\hline
\end{tabular}

Data are presented as means, numbers in brackets are standard error of the mean. ${ }^{a}$ diameter at breast height, ${ }^{b}$ root collar diameter, ${ }^{c}$ total above-ground biomass, ${ }^{d}$ total below- ground biomass including stump/root bole, ${ }^{e}$ total root mass excluding the stump/root bole

or root-collar diameter. Because the trial plants were young and the number of replicates low, fitting trend lines with limited data may not be appropriate. However, in other root studies, power-law curves have been fitted to limited data sets to provide some predictive ability (e.g. McIvor et al. 2009; Phillips et al. 2013a). Using the trial data, it was possible to generate simple relationships between root collar diameter and growth attributes with reasonable $r^{2}$ values as shown in Table 7 for total root length and belowground biomass.

In a similar manner, allometric relationships can be generated if all the data are combined (Equations 1 and 2).

$$
\begin{aligned}
& \text { Total root length }(\mathrm{m})=0.009 \text { root-collar diameter }{ }^{2.22}(\mathrm{~mm}) \\
& \mathrm{R}^{2}=0.83
\end{aligned}
$$

Below-ground biomass $(\mathrm{g})=0.012$ root-collar $\operatorname{diameter}^{2.63}(\mathrm{~mm})$ $\mathrm{R}^{2}=0.89$

\section{Discussion}

The differences in initial height among species is probably the biggest factor in interspecies variation in the parameters measured for the early years of growth, though the physiological age of all species was roughly similar (Table 1). Species like alder, cherry, and oak were considerably larger at time of planting than radiata and Douglas-fir (Fig. 2), and this continued to show for the first year or two of growth in the trial plot. Rather than having planting materials of the same size and grade, our trial used "nursery-raised" planting grades as would normally be used by the forestry or "land management" sectors. This may have been a shortcoming in trial

\begin{tabular}{|c|c|c|c|c|c|c|c|c|c|}
\hline Attribute & Oak & Eucalypt & Douglas-fir & Redwood & Cherry & Blackwood & Alder & Cypress & Radiata \\
\hline Trees sampled & 2 & 2 & - & 2 & 2 & 3 & 1 & 2 & 3 \\
\hline Tree height (m) & $1.85(0.45)$ & $3.65(0.35)$ & - & $2.50(0.60)$ & $2.70(0.50)$ & $3.37(0.08)$ & 6.43 & $4.00(0.90)$ & $1.32(0.38)$ \\
\hline Canopy spread (m) & $1.95(0.40)$ & $2.03(0.27)$ & - & $2.53(0.53)$ & $1.93(0.87)$ & $2.22(0.42)$ & 4.4 & $3.23(0.73)$ & $2.67(0.73)$ \\
\hline $\mathrm{DBH}^{\mathrm{a}}(\mathrm{mm})$ & $12(\mathrm{~N} / \mathrm{A})$ & $40(1.5)$ & - & $34(24.0)$ & $28(6.0)$ & $52(1.5)$ & 80 & $84(39.0)$ & $71(3.0)$ \\
\hline $\mathrm{RCD}^{\mathrm{b}}(\mathrm{mm})$ & $82(0.25)$ & $94(11.5)$ & - & $91(32.0)$ & $101(32.5)$ & $107(9.3)$ & 129 & $158(32.0)$ & $103(25.2)$ \\
\hline Max. root diameter $(\mathrm{m})$ & $1.50(1.10)$ & $4.50(0.30)$ & - & $3.10(0.50)$ & $3.20(1.70)$ & $6.93(1.69)$ & 7.70 & $5.60(0.40)$ & $3.27(1.11)$ \\
\hline Max. root depth (m) & $0.35(0.05)$ & $0.30(0.05)$ & - & $0.28(0.03)$ & $0.28(0.08)$ & $0.32(0.02)$ & 0.50 & $0.35(0.05)$ & $2.27(0.03)$ \\
\hline Total AGB $^{C}(\mathrm{~g})$ & $1098(628)$ & $4743(876)$ & - & $3921(2468)$ & $4552(3625)$ & $6834(2055)$ & 12071 & $28942(17326)$ & $6848(3384)$ \\
\hline Total BGB ${ }^{\mathrm{d}}(\mathrm{g})$ & $1022(711)$ & $1561(260)$ & - & $1129(506)$ & $6200(5807)$ & $2520(770)$ & 8959 & $5088(2596)$ & $2046(945)$ \\
\hline Total root mass ${ }^{\mathrm{e}}(\mathrm{g})$ & $483(370)$ & $1022(160)$ & - & $605(253)$ & $4780(4549)$ & $1595(456)$ & 8117 & $2954(1296)$ & $1268(617)$ \\
\hline Total root length $>1 \mathrm{~mm}(\mathrm{~m})$ & $94.7(51.8)$ & $83.0(38.7)$ & - & $208.3(70.0)$ & $403.2(357.4)$ & $209.3(81.8)$ & 1268.7 & $837.4(431.7)$ & $128.1(46.3)$ \\
\hline
\end{tabular}

Table 5 Attributes for 3-year-old trialled species

Data are presented as means (with the exception of Alder), numbers in brackets are standard error of the mean. ${ }^{a}$ diameter at breast height, ${ }^{b}$ root collar diameter,

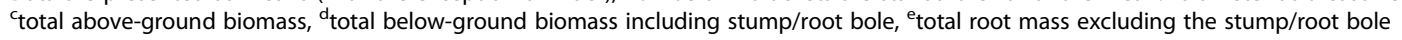




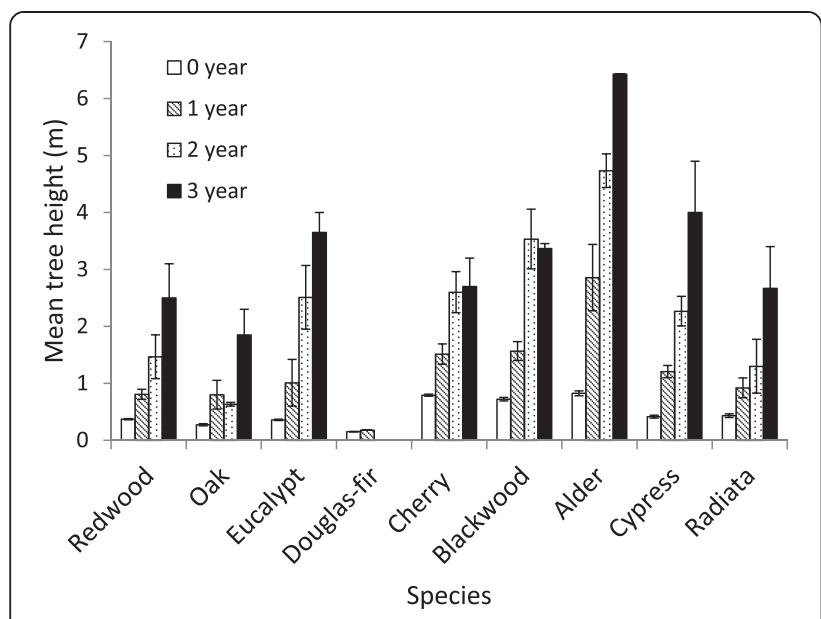

Fig. 4 Mean tree heights for nine trial species 0-3 years after planting. Vertical bars are one standard error of the mean

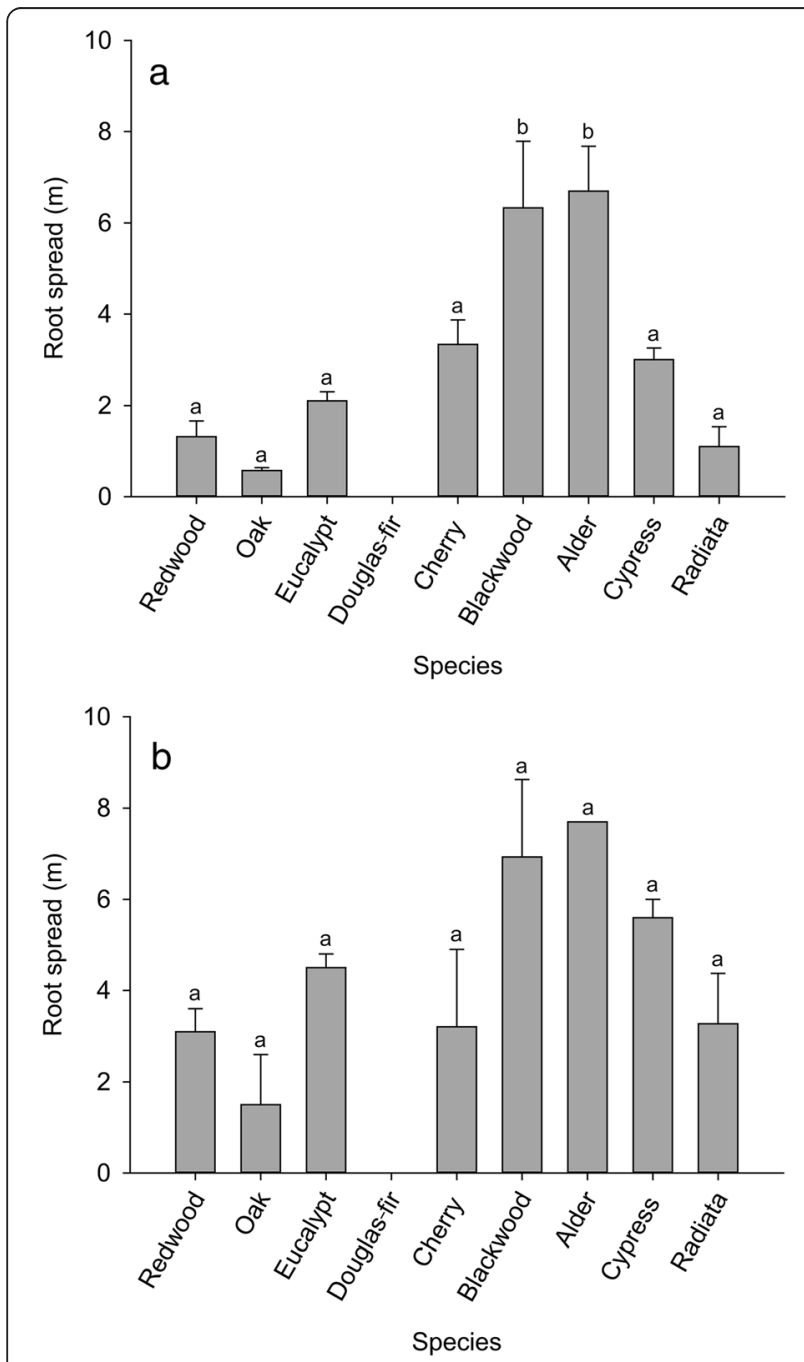

Fig. 5 Mean root spread in Year 2 (a) and Year 3 (b) for the nine trial species. Error bars represent one standard error of the mean; bars with different letters were significantly different $(P<0.001)$

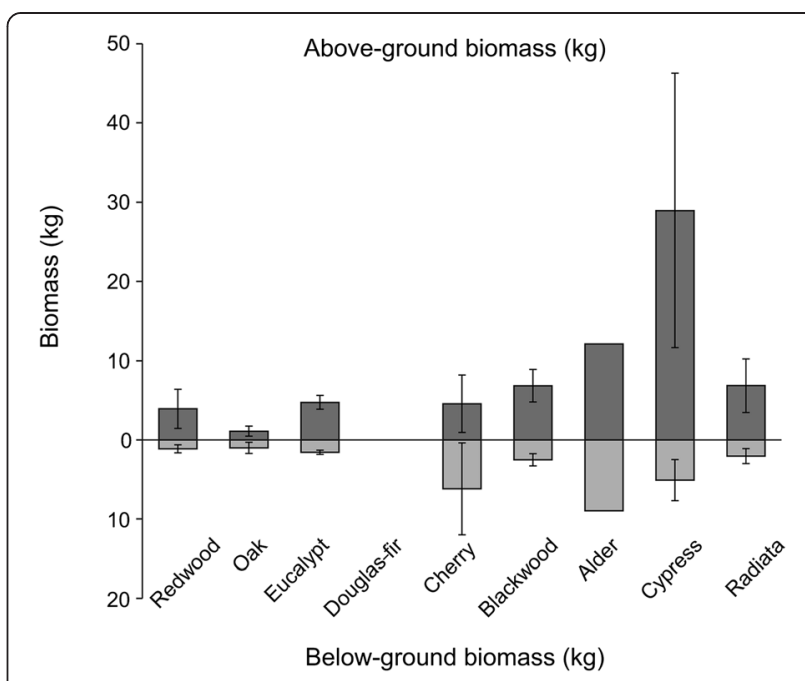

Fig. 6 Plant biomass above- (dark bars) and below-ground (light bars) in Year 3. Error bars represent one standard error of the mean for each of above- and below-ground components of biomass. Mean values except for alder

design. In hindsight, it would have been preferable for seedlings to have been of the same size/grade, though the growth in early years probably reflects the actual performance and practice of nursery-raised and supplied stock. However, in another trial but using native species, where size at planting and nursery treatment were highly variable, in the first 3-5 years no difference was found in survival or growth between plants raised in openground compared with those grown in larger containers for the shrub hardwood and monocot species trialled (Cole et al. 2014).

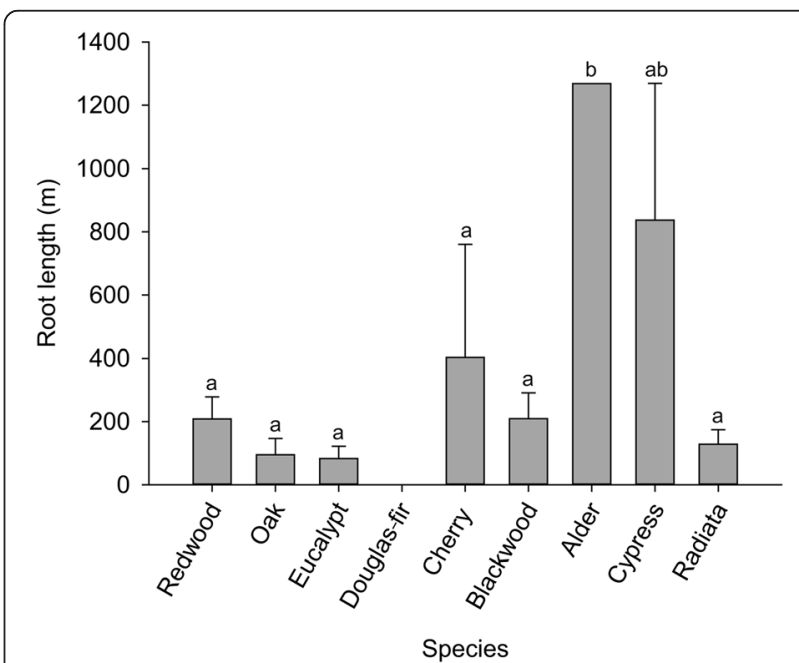

Fig. 7 Mean total root length (roots $>1 \mathrm{~mm}$ in diameter) of trial species in Year 3. Error bars represent one standard error of the mean; bars with different letters were significantly different $(P=0.006)$ 
Table 6 Mean total root length $(\mathrm{m})$ by root diameter size class $(\mathrm{mm})$ with radial distance from stem $(\mathrm{m})$

\begin{tabular}{|c|c|c|c|c|c|c|c|c|c|c|c|}
\hline \multirow[b]{2}{*}{ Species } & \multirow[b]{2}{*}{ Root diameter class (mm) } & \multicolumn{10}{|c|}{ Radial distance from stem (m) } \\
\hline & & $0-0.5$ & $>0.5-1.0$ & $>1.0-1.5$ & $>1.5-2.0$ & $>2.0-2.5$ & $>2.5-3.0$ & $>3.0-3.5$ & $>3.5-4.0$ & $>4.0-4.5$ & $>4.5-5.0$ \\
\hline \multirow[t]{6}{*}{ Oak } & $1-2$ & 22.0 & 22.2 & 12.1 & 5.5 & & & & & & \\
\hline & $>2-5$ & 16.2 & 8.7 & 2.7 & 0.4 & & & & & & \\
\hline & $>5-10$ & 4.8 & 1.8 & & & & & & & & \\
\hline & $>10-20$ & 1.7 & 0.3 & & & & & & & & \\
\hline & $>20-50$ & 0.6 & & & & & & & & & \\
\hline & Total root length $(\mathrm{m})$ & 45.2 & 33.0 & 14.8 & 5.9 & & & & & & \\
\hline \multirow[t]{7}{*}{ Eucalypt } & $1-2$ & 9.8 & 20.6 & 7.9 & 2.9 & 1.9 & 1.0 & & & & \\
\hline & $>2-5$ & 5.5 & 8.9 & 6.4 & 4.2 & 1.8 & 1.0 & & & & \\
\hline & $>5-10$ & 3.0 & 2.0 & 1.6 & 0.6 & 0.3 & & & & & \\
\hline & $>10-20$ & 0.8 & 1.0 & 0.4 & & & & & & & \\
\hline & $>20-50$ & 1.0 & 0.4 & & & & & & & & \\
\hline & $>50-100$ & 0.2 & & & & & & & & & \\
\hline & Total root length (m) & 20.3 & 32.9 & 16.3 & 7.8 & 4.0 & 2.0 & & & & \\
\hline Douglas-fir & No data at age 3 & & & & & & & & & & \\
\hline \multirow[t]{6}{*}{ Redwood } & $1-2$ & 74.3 & 65.5 & 28.6 & 8.6 & & & & & & \\
\hline & $>2-5$ & 22.7 & 8.0 & 1.6 & & & & & & & \\
\hline & $>5-10$ & 3.1 & 0.7 & & & & & & & & \\
\hline & $>10-20$ & 0.5 & & & & & & & & & \\
\hline & $>20-50$ & 0.3 & & & & & & & & & \\
\hline & Total root length (m) & 100.9 & 74.2 & 30.2 & 8.6 & 0.0 & & & & & \\
\hline \multirow[t]{7}{*}{ Cherry } & $1-2$ & 42.3 & 80.8 & 182.7 & 111.4 & 22.2 & 0.8 & & & & \\
\hline & $>2-5$ & 18.4 & 29.8 & 52.7 & 26.9 & 4.0 & & & & & \\
\hline & $>5-10$ & 7.2 & 8.4 & 6.8 & 0.6 & & & & & & \\
\hline & $>10-20$ & 3.7 & 8.2 & 1.1 & & & & & & & \\
\hline & $>20-50$ & 3.5 & 3.2 & 0.2 & & & & & & & \\
\hline & $>50-100$ & 1.0 & & & & & & & & & \\
\hline & Total root length (m) & 76.2 & 130.3 & 243.5 & 138.9 & 26.2 & 0.8 & & & & \\
\hline \multirow[t]{7}{*}{ Blackwood } & $1-2$ & 7.7 & 23.6 & 31.7 & 26.1 & 21.2 & 13.6 & 9.9 & 7.7 & 0.3 & 0.5 \\
\hline & $>2-5$ & 6.2 & 11.8 & 13.6 & 8.0 & 8.7 & 5.3 & 6.3 & 0.7 & & \\
\hline & $>5-10$ & 4.0 & 4.5 & 2.8 & 0.7 & 0.7 & & & & & \\
\hline & $>10-20$ & 3.5 & 2.4 & & & & & & & & \\
\hline & $>20-50$ & 1.5 & 0.3 & & & & & & & & \\
\hline & $>50-100$ & 0.2 & & & & & & & & & \\
\hline & Total root length (m) & 23.2 & 42.6 & 48.1 & 34.9 & 30.6 & 18.9 & 16.2 & 8.4 & 0.3 & 0.5 \\
\hline \multirow[t]{7}{*}{ Alder } & $1-2$ & 64.0 & 127.7 & 131.0 & 154.0 & 101.1 & 95.6 & 52.0 & 22.7 & 5.1 & 2.7 \\
\hline & $>2-5$ & 36.1 & 56.5 & 54.5 & 61.2 & 43.3 & 34.8 & 22.8 & 73.8 & 1.7 & 0.6 \\
\hline & $>5-10$ & 18.8 & 23.0 & 17.1 & 14.5 & 12.2 & 6.0 & 2.5 & 0.6 & & \\
\hline & $>10-20$ & 7.0 & 7.8 & 4.1 & 2.1 & 3.5 & 1.4 & 0.7 & & & \\
\hline & $>20-50$ & 5.2 & 0.9 & & & & & & & & \\
\hline & $>50-100$ & 0.4 & & & & & & & & & \\
\hline & Total root length $(\mathrm{m})$ & 131.5 & 215.8 & 206.7 & 231.8 & 160.1 & 137.7 & 78.0 & 97.1 & 6.7 & 3.3 \\
\hline
\end{tabular}


Table 6 Mean total root length $(\mathrm{m})$ by root diameter size class $(\mathrm{mm})$ with radial distance from stem $(\mathrm{m})$ (Continued)

\begin{tabular}{llllllll}
\hline Cypress & $1-2$ & 75.3 & 106.9 & 139.8 & 160.1 & 98.8 & 49.7 \\
& $>2-5$ & 48.5 & 64.4 & 49.1 & 14.8 & 3.1 & \\
& $>5-10$ & 21.8 & 15.8 & 3.2 & 0.0 & & \\
& $>10-20$ & 8.2 & 0.5 & & & & \\
& $>20-50$ & 1.9 & & & & & \\
& $>50-100$ & 0.1 & & & & & \\
& Total root length $(\mathrm{m})$ & 155.8 & 187.7 & 192.1 & 175.0 & 102.0 & 49.7 \\
\hline Radiata & $1-2$ & 30.7 & 26.3 & 29.9 & 19.7 & 8.0 & 1.4 \\
& $>2-5$ & 13.2 & 11.0 & 7.7 & 5.0 & 1.2 & \\
& $>5-10$ & 3.1 & 7.9 & 3.6 & 0.8 & & \\
& $>10-20$ & 1.3 & 2.0 & 0.4 & & & \\
& $>20-50$ & 2.2 & 0.2 & & & & \\
& Total root length $(\mathrm{m})$ & 50.4 & 47.4 & 41.6 & 25.4 & 9.3 & 1.4 \\
\hline
\end{tabular}

While differences in performance existed in the early years post-planting, by Year 3, some of the smaller seedlings such as radiata, redwood, and cypress had "caught up" to the better early performers and exhibited strong growth between Years 2 and 3. While general observations can be made about plant performance in early years as above, it is accepted that real differences between species are unlikely to emerge until the plants are considerably older - at least beyond 4 years from planting.

The differences observed in plant growth may also be attributed to environmental factors such as the presence of a high water table at the time of establishment, which for some species such as Douglas-fir may have been an

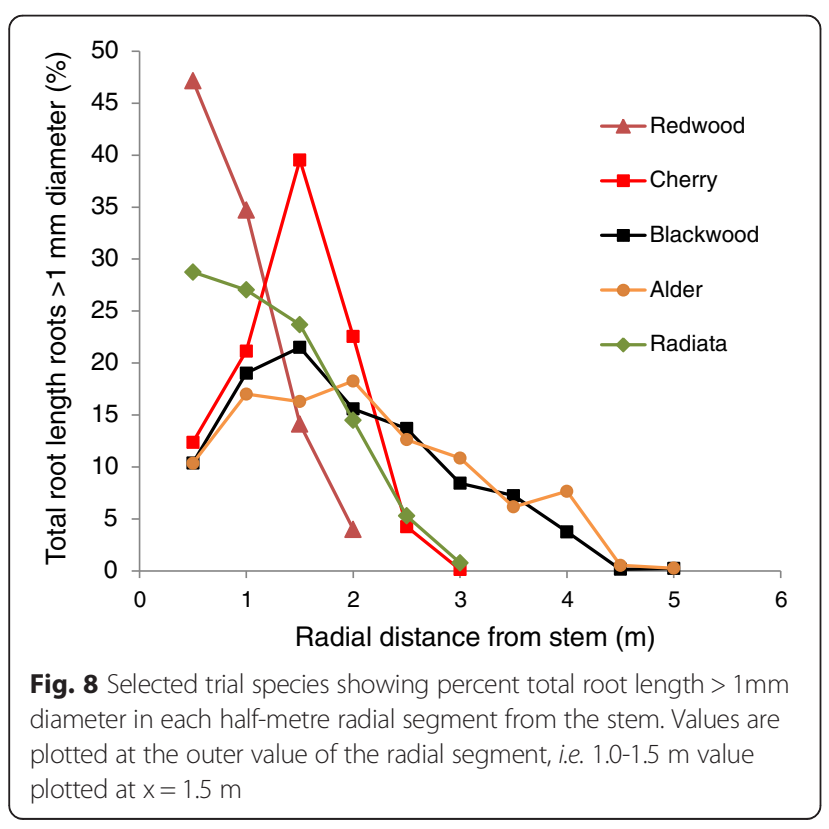

inhibiting factor and ultimately was probably responsible for their non-survival, while in others such as alder it may have enhanced growth. The rapid growth of alder may also be due to it being both a natural coloniser species and its ability to fix nitrogen. Edaphic factors such as soil type are often cited as the major controlling factor on plant growth (e.g. Phillips and Watson 1994). However, the trial site was reasonably uniform and the soil being a sandy loam without stones provided an ideal growing medium that did not impede the lateral root growth of the plants. However, the presence of the seasonal water table and apparent increase in soil density beyond $0.5 \mathrm{~m}$ depth may have limited the development of vertical root growth.

After 3 years' growth, it is clear that some species outperformed others in terms of the metrics deemed important for soil reinforcement and hence erosion control (e.g., total root length, root depth, root spread, etc.) (Marden et al. 2005). Whether these levels of performance persist beyond 3 years is unknown. Notwithstanding the limited sample sizes or the fact that the trial site may have been more or less favourable than others for establishment and juvenile growth, it may still be possible to compare "performance" metrics with other species for which root data exists. Comparing species grown in earlier trials on the same site with those from this study suggest that in terms of total root length, the best performing species from this trial exceeded those of native woody species (Marden et al. 2005) but are less than poplar and willows grown from poles after 3 years (Phillips et al. 2014 and from unpublished data).

The primary objective of this study was to assess potential candidates for future 'erosion control forests' so comparisons with the root characteristics of the most commonly used species in New Zealand forestry (radiata 
Table 7 Allometric relationships for trialled species

\begin{tabular}{|c|c|c|c|c|}
\hline Species & $\begin{array}{l}\text { Root-collar diameter }(x, \mathrm{~mm}) \text { vs } \\
\text { total root length }(y, \mathrm{~m})\end{array}$ & $R^{2}$ & $\begin{array}{l}\text { Root-collar diameter }(x, m m) \text { vs } \\
\text { below-ground biomass }(y, g)\end{array}$ & $\mathrm{R}^{2}$ \\
\hline Redwood & $y=0.02 x^{1.97}$ & 0.72 & $y=0.02 x^{2.36}$ & 0.94 \\
\hline Oak & $y=0.03 x^{1.81}$ & 0.97 & $y=0.19 x^{1.93}$ & 0.94 \\
\hline Eucalypt & $y=0.002 x^{2.31}$ & 0.99 & $y=0.002 x^{2.87}$ & 0.98 \\
\hline Douglas-fir & No data & & No data & \\
\hline Cherry & $y=0.026 x^{2.05}$ & 0.80 & $y=0.04 x^{2.5}$ & 0.83 \\
\hline Blackwood & $y=0.017 x^{2.01}$ & 0.91 & $y=0.012 x^{2.66}$ & 0.95 \\
\hline Alder & $y=0.027 x^{2.19}$ & 0.89 & $y=0.09 x^{2.31}$ & 0.93 \\
\hline Cypress & $y=0.063 x^{1.90}$ & 0.87 & $y=0.04 x^{2.41}$ & 0.84 \\
\hline Radiata pine & $y=0.064 x^{1.62}$ & 0.88 & $y=0.014 x^{2.46}$ & 0.96 \\
\hline
\end{tabular}

Relationships are shown between root collar diameter and total root length $>1 \mathrm{~mm}$ diameter $(\mathrm{m})$ and below-ground biomass $(\mathrm{g})$

pine) are important. However, direct comparisons for many attributes are not possible largely because earlier studies of radiata root systems only examined "structural roots", i.e. those greater than $2 \mathrm{~mm}$ in diameter. In addition, these earlier studies did not examine or report the radial distribution of root information. To enable comparison with previous studies, the 1-2 mm diameter class information has to be removed from the current results. For example, three-year-old radiata mean total root length $>2 \mathrm{~mm}$ diameter from this study was $42.5 \mathrm{~m}$ $(\mathrm{n}=3$, range 9 to $62 \mathrm{~m}$ ). This is similar to that reported for a Tauranga trial $(56 \mathrm{~m}, \mathrm{n}=5)$ and more than from a Taranaki trial (15 m, n=5) (Watson and Tombleson $2002,2004)$. It was, however, considerably less than from a hillslope growth factor trial of 3-year-old radiata plantings, which had a mean root length of $95.5 \mathrm{~m}(\mathrm{n}=25)$ (Marden unpublished data). Further, mean total root lengths $>2 \mathrm{~mm}$ diameter for alder $(512 \mathrm{~m}, \mathrm{n}=1)$, cypress (232 $\mathrm{m}, \mathrm{n}=2)$ and cherry $(121 \mathrm{~m}, \mathrm{n}=2)$ exceed all reported values for radiata total root lengths at age 3 . It is not possible to compare total root length by root diameter and distance from the stem for radiata as these data are not available from those earlier studies. As might be expected, the coarsest roots are located closest to the stem in all the species trialled. Lateral roots closest to the stem tend to increase diameter growth in response to an abiotic stress such as wind or slope (Telewski 1995). Cherry had the greatest length of roots in the largest diameter class $(50-100 \mathrm{~mm})$. All species had some roots in the $20-50 \mathrm{~mm}$ diameter class. Alder $(5.2 \mathrm{~m})$, cherry $(3.5 \mathrm{~m})$, and radiata $(2.2 \mathrm{~m})$ had the greatest length of roots in this diameter class.

The mean maximum root spread for each trialled species shows a similar pattern to that for total root length $>1 \mathrm{~mm}$, with alder $(7.7 \mathrm{~m})$, blackwood $(6.9 \mathrm{~m})$ and cypress $(5.6 \mathrm{~m})$ having the greatest lateral root spread. Alder and cypress also have greater root density and a more even proportion of total root length from the stem as well as occupying more soil around the stem than the other species tested (Fig. 3, Table 6). The mean maximum root spread of radiata from this trial at Year 3 $(3.3 \mathrm{~m})$ was close to that recorded from a growth factor seedling trial on a hillslope near Gisborne $(3.8 \mathrm{~m}$ ) (Marden unpublished data).

\section{Use of trialled species for erosion control}

Several of the trialled species have specifically been recommended for, or are commonly used for, erosion control in New Zealand (e.g. Van Kraayenoord and Hathaway 1986) and elsewhere (e.g. USDA Natural Resource Conservation Centre United States Department of Agriculture and Natural Resources Conservation 2014). Alder species, for example, are used in many countries as parts of bioengineering control programmes (e.g. Naghdhi et al. 2013; Stokes et al. 2009). Further, some of the trialled species have uses beyond soil stabilisation, such as for timber production (e.g. blackwood, redwood) while others are often used for amenity or aesthetics (cherry, oak). Overall, in terms of their potential for root reinforcement and erosion control, the top performers from this trial were alder, cherry, blackwood, radiata, and redwood, with eucalypt and oak showing the least potential largely because their total root lengths were the lowest. It is not possible, however, to provide details on factors that might limit either the establishment of, or use of any particular trialled species across New Zealand as the variation in site requirements are wide in relation to optimum performance. However, the fact that many of these species can be seen growing in a wide range of climatic, soil type, and slope positions across New Zealand suggests that they may be able to be established.

Metrics such as total root length can be used to infer the potential soil reinforcement capability of species through either direct comparison or through modelling site occupancy (Phillips et al. 2011). Results from this trial when compared with those from earlier studies grown on the same site under similar climatic conditions 
as outlined above, indicate a wide range of performance (Fig. 9). The similar root attributes of alder to the currently preferred soil conservation species poplar and willow (rapid growth, extensive lateral spread) suggest it is a prime candidate for consideration as an erosion control species (notwithstanding potential issues such as 'wildling' spread; e.g. Stanley 2002). This supports the view that some introduced species, many of which may be colonising species in their country of origin, may make excellent candidates for use in soil conservation and for controlling shallow landslide erosion (van Kraayenoord and Hathaway 1986). For example, alders have been widely used for revegetating and ameliorating infertile industrially disturbed sites in Europe, the U. S. and Japan and Italian alder (Alnus cordata (Lois.) Desf.) has been used to consolidate landslips (ibid).

Because tree root excavations are time-consuming, only a limited number of investigations of whole tree/ plant root systems have been carried out in New Zealand and internationally. Further, time-series growth performance trials in which below-ground tree growth attributes such as biomass, root architecture, and total root length are assessed, are also limited. Many studies, including this one, involve assessment of only one, or a few specimens, of different ages and usually from only one site. This restricts the data available to make inter-species comparisons and also limits the capability to develop statisticallyreliable predictive models/tools. However, by using simple allometric relationships such as described above, it may be possible to begin to model more complex relationships between plant numbers, plant performance, and time since planting to assess when forests or groups of trees begin to contribute significantly to soil reinforcement and slope stabilisation (e.g. Schwarz et al. 2013). This would help meet a need identified by Stokes et al. (2014) to allay fears in the civil and geotechnical engineering communities, who are still wary about using soft engineering structures and associated vegetation.

\section{Conclusions}

This trial of nine exotic tree species has provided important new information and expanded the knowledge base of root growth and performance of young tree species in New Zealand. When compared with similar age Pinus radiata root information, all the trialled species other than Douglas-fir (which did not survive) showed some potential for use in erosion control based on their root attributes. However, root-system development beyond the term of this trial and its limitation to only one site and soil type, precludes more definitive statements on the widespread use of the trialled species for erosion control across New Zealand. The best overall performer was alder with cherry, cypress, blackwood, and redwood also performing well across the range of metrics assessed.

Though based on limited data, regression relationships established for individual species between above- and below-ground growth parameters at different stages of growth, are useful for determining planting density requirements for situations where trees are the preferred soil conservation practice to prevent shallow landslides on New Zealand's erosion-prone hill country. These relationships assist in determining when canopy closure or root site occupancy will occur (Phillips et al. 2011) which in turn helps determine when that species might become "effective" in terms of providing an erosion control function. However, the paucity of below-ground tree root data globally still limits our ability to develop and refine predictive models for different species and to refine or

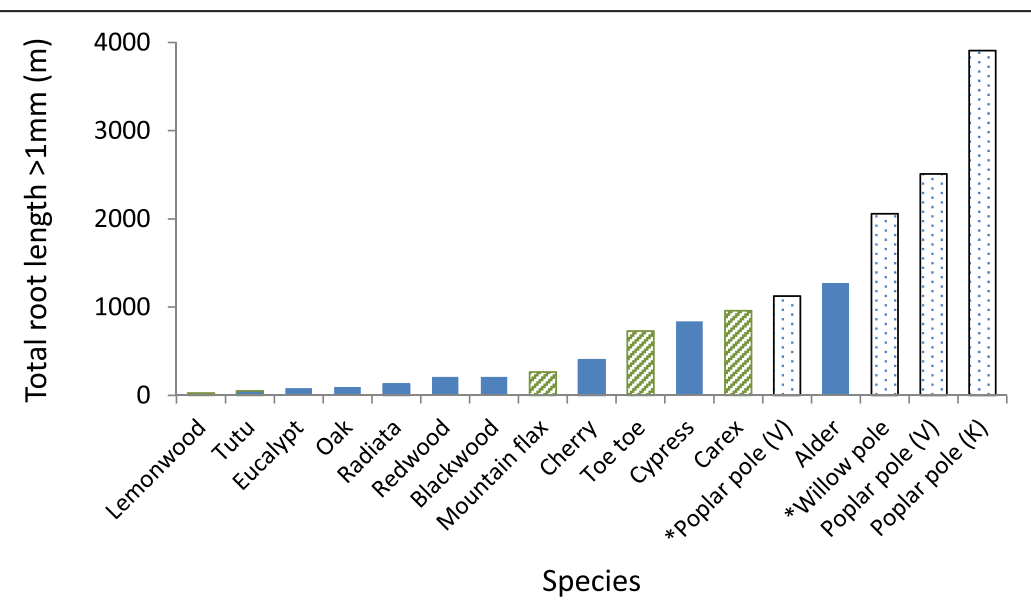

Fig. 9 Total root length (roots $>1 \mathrm{~mm}$ diameter) from this trial (solid blue bars) compared with existing 3-year-old data from other species trialled at the same site. Mean values except for toe toe, carex, alder, poplar, and willow. Native species (green diagonal shading - Marden et al. 2005). Poplars ( $V=$ 'Veronese'; K = 'Kawa') and willow (lightly stippled bars $-\mathrm{C}$. Phillips unpublished data). * =2-year-old data 
enhance recommendations on tree density and pattern to achieve erosion control. Root observations such as those presented here make a contribution to improving our understanding of how and when, and at what density, plantings become effective for controlling erosion. However, the statistical power of relationships reported here, are acknowledged as being weak, and reflect the generally low sample numbers obtained in most international root system studies for trees beyond a few years old.

If similar trials are contemplated in future to obtain accurate interspecies comparisons in the early years of plant growth, it is recommended that plant materials should be of a similar size at the time of establishment where possible and of similar physiological age, even though nursery and planting practices result in different sized materials being sold and planted.

\section{Endnote}

"Coarse" is used here to mean roots greater than 1 mm diameter.

\section{Competing interests}

There are no competing interests.

\section{Authors' contributions}

$\mathrm{CP}$ and $\mathrm{MM}$ conceived the idea for the trial during discussions with Scion and contributed to plant extractions and processing. CP drafted the initial manuscript and MM refined it. SL contributed to plant extractions and processing, data management and performed the statistical analysis. All authors read and approved the final manuscript.

\section{Acknowledgements}

We thank Richard Hemming, Stephen Hough, interns Sophie Michel, Georg Richter and volunteer Alex Watson for assisting with plant extraction and processing during this trial; Guy Forrester for help in designing the trial; and Christine Bezar for editing services. The Eastland Institute of Technology (formerly Tairawhiti Polytechnic) is thanked for providing the land on which this and earlier plant trials were located. Comments and suggestions from two reviewers have significantly improved the final paper. This research was funded from Future Forests Research and Scion via MBIE contract C04X0806 "Forestry and Environment".

\section{Author details}

'Landcare Research, PO Box 69040, Lincoln 7640, New Zealand. '2 Landcare Research, PO Box 445, Gisborne 4010, New Zealand. 'Landcare Research, Private Bag 3127, Hamilton 3240, New Zealand.

Received: 8 December 2014 Accepted: 23 June 2015

Published online: 14 August 2015

\section{References}

Basher, LR. (2013). Erosion processes and their control in New Zealand. In JR Dymond (Ed.), Ecosystem services in New Zealand - conditions and trends (pp. 363-374). Lincoln, New Zealand: Manaaki Whenua Press.

Blaschke, P, Hicks, D, \& Meister, A. (2008). Quantification of the flood and erosion reduction co-benefits, and co-costs, of climate change mitigation measures in New Zealand. Wellington: Ministry for the Environment.

Brang, P, Schonenberger, W, Ott, E, \& Gardner, B. (2001). Forests as protection from natural hazards. In J Evans (Ed.), Applying forest science for sustainable management (pp. 53-81). Oxford: Blackwell Science.

Cole, C, Bergin, D, Kimberley, M. (2014). Establishment performance of native shrubs - a comparison of container and open-ground plants.Technical Article No. 5.4. Tane's Tree Trust. http://maxa.maf.govt.nz/sff/about-projects/search/ L12-098/ttt-technical-article-2.pdf. Accessed 16 April 2014.

Crozier, MJ. (2005). Multiple-occurrence regional landslide events in New Zealand: hazard management issues. Landslides, 2, 247-256. doi:10.1007/s10346-005-0019-7.
Czernin, A, \& Phillips, CJ. (2005). Below-ground morphology of Cordyline australis (New Zealand cabbage tree) and its suitability for riverbank stabilisation. New Zealand Journal of Botany, 43, 851-864. doi:10.1080/ $0028825 X .2005 .9512995$.

Danjon, F, Bert, D, Godin, C, \& Trichet, P. (1999). Structural root architecture of 5year-old Pinus pinaster measured by $3 \mathrm{D}$ digitising and analysed with AMAPmod. Plant and Soil, 217(1-2), 49-63. doi:10.1007/978-94-017-3469-1_6.

Docker, BB, \& Hubble, TCT. (2008). Quantifying root-reinforcement of river bank soils by four Australian tree species. Geomorphology, 100, 401-418. doi:10.1016/j.geomorph.2008.01.009.

Douglas, GB, Mclvor, IR, Manderson, AK, Koolaard, JP, Todd, M, Braaksma, S, \& Gray, RAJ. (2011). Reducing shallow landslide occurrence in pastoral hill country using wide-spaced trees. Land Degradation \& Development, 24, 103-114. doi:10.1002/ldr.1106.

Ekanayake, JC, \& Phillips, CJ. (1999). A method for stability analysis of vegetated hillslopes: an energy approach. Canadian Geotechnical Journal, 36, 11721184. doi:10.1139/t99-060.

Ekanayake, JC, \& Phillips, CJ. (2002). Slope stability thresholds for vegetated hillslopes: a composite model. Canadian Geotechnical Journal, 39, 849-862. doi:10.1139/ t02-026.

Hewitt, AE. (2010). New Zealand soil classification. 3nd edn. Landcare research science series 1. Lincoln: Manaaki Whenua Press.

Mao, Z, Jourdan, C, Bonis, M, Pailler, F, Rey, H, Saint-André, L, \& Stokes, A. (2013). Modelling root demography in heterogeneous mountain forests and applications for slope stability analysis. Plant and Soil, 363, 357-382. doi:10.1007/s11104-012-1324-2

Marden, M, \& Rowan, D. (1993). Protective value of vegetation on tertiary terrain before and during Cyclone Bola, east coast, North Island, New Zealand. New Zealand Journal of Forestry Science, 23, 255-263.

Marden, M, Rowan, D, \& Phillips, CJ. (2005). Stabilising characteristics of New Zealand indigenous riparian colonising plants. Plant and Soil, 278, 95-105. doi:10.1007/s11104-004-7598-2.

Marden, M, Rowan, D, \& Phillips, C. (2008). Recurrent displacement of a forested earthflow and implications for forest management, East Coast Region, New Zealand. In J Schmidt, T Cochrane, C Phillips, S Elliott, T Davies, \& L Basher (Eds.), Sediment dynamics in changing environments (pp. 491-501). Wallingford, UK: International Association of Hydrological Sciences. Publication 325.

Marden, M, Arnold, G, Seymour, A, \& Hambling, R. (2012). History and distribution of steepland gullies in response to land use change, East Coast region, North Island. Geomorphology, 153(154), 81-90. doi:10.1016/ j.geomorph.2012.02.011.

Mclvor, IR, Douglas, GB, \& Benavides, R. (2009). Coarse root growth of Veronese poplar trees varies with position on an erodible slope in New Zealand. Agroforestry Systems, 76, 251-264. doi:10.1007/s10457-009-9209-y.

Ministry of Agriculture and Forestry. (2008). Future drivers for New Zealand forestry. Wellington, New Zealand: MAF.

Ministry of Agriculture and Forestry (2010). Sustainable land management hill country erosion programme. Wellington, New Zealand: MAF. http:// www.mpi.govt.nz/funding-and-programmes/natural-resources/sustainable-landmanagement-and-hill-country-erosion-programme/. Accessed 1 July 2015.

Mulatya, JM, Wilson, J, Ong, CK, Deans, JD, \& Sprent, JI. (2002). Root architecture of provenances, seedlings and cuttings of Melia volkensii: implications for crop yield in dryland agroforestry. Agroforestry Systems, 56, 65-72. doi:10.1023/A:1021165830511.

Naghdi, R, Maleki, S, Abdi, E, Mousavi, R, \& Nikooy, M. (2013). Assessing the effect of Alnus roots on hillslope stability to use in soil bioengineering. Journal of Forest Science, 59(11), 417-423.

New Zealand Forest Owners Association (2013). http://www.nzfoa.org.nz/ plantation-forestry Accessed 1 July 2015

O'Loughlin, CL. (2005). The protective role of trees in soil conservation. N Z J For $49(4), 9-15$.

O'Loughlin, CL, \& Zhang, X. (1986). The influence of fast-growing conifer plantations on shallow landsliding and earthflow movement in New Zealand steepland (pp. 217-226). Ljublijana, Yugoslavia: Proceedings 18th IUFRO World Congress. Division 1, Volume 1.

Parkner, T, Page, M, Marden, M, \& Marutani, T. (2007). Gully systems under undisturbed indigenous forest, East Coast Region, New Zealand. Geomorphology, 84, 241-253. doi:10.1016/j.geomorph.2006.01.042.

Phillips, CJ, \& Marden, M. (2005). Reforestation schemes to manage regional landslide risk. In T Glade, M Anderson, \& MJ Crozier (Eds.), Landslide hazard and risk (pp. 517-547). Chichester: John Wiley. 
Phillips, CJ, \& Watson, AJ. (1994). Landcare research science series 7. Lincoln, New Zealand: Manaaki Whenua Press. Structural tree root research in New Zealand, a review.

Phillips, CJ, Marden, M, \& Pearce, AJ. (1990). Effectiveness of reforestation in prevention and control of landsliding during large cyclonic storms. In Proceedings of International Union of Forest Research Organisations XIX World Congress, 1, 340-350.

Phillips, CJ, Ekanayake, JC, \& Marden, M. (2011). Root site occupancy modelling of young New Zealand native plants: implications for soil reinforcement. Plant and Soil, 346, 201-214. doi:10.1007/s11104-011-0810-2.

Phillips, C, Marden, M, \& Basher, L. (2012). Plantation forest harvesting and landscape response - what we know and what we need to know. New Zealand Journal of Forestry Science, 56(4), 4-12.

Phillips, CJ, Marden, M, Lambie, S, Watson, A, Ross, C, \& Fraser, S. (2013a). Observations of below-ground characteristics of young redwood trees (Sequoia sempervirens) from two sites in New Zealand - implications for erosion control. Plant Soil, 363, 33-48. doi:10.1007/s11104-012-1286-4.

Phillips, CJ, Rey, F, Marden, M, \& Liebault, F. (2013b). Revegetation of steeplands in France and New Zealand: geomorphic and policy responses. New Zealand Journal of Forestry Science, 43, 14. doi:10.1186/1179-5395-43-14.

Phillips, CJ, Marden, M, \& Lambie, S. (2014). Observations of root growth of young poplar and willow planting types. New Zealand Journal of Forestry Science, 44, 15. doi:10.1186/s40490-014-0015-6.

Schwarz, M, Lehmann, P, \& Or, D. (2010). Quantifying lateral root reinforcement in steep slopes from a bundle of roots to tree stands. Earth Surface Processes and Landforms, 35, 354-367. doi:10.1002/esp.1927.

Schwarz, M, Giadrossich, F, \& Cohen, D. (2013). Modeling root reinforcement using root-failure Weibull survival function. Hydrology and Earth System Sciences. Discussion, 10(3), 3843-3868. doi:10.5194/hessd-10-3843-2013.

Sidle, RC, \& Ochiai, H. (2006). Landslides: processes, prediction, and land use. water resources monograph 18. Washington, DC: American Geophysical Union.

Sidle, RC, Pearce, AJ, \& O'Loughlin, CL. (1985). Hillslope stability and land use water resources monograph 11. Washington, DC: American Geophysical Union.

Smaill, SJ, Bayen, KM, Coker, GWR, Paul, TSH, \& Clinton, PW. (2014). The right tree for the job? Perceptions of species suitability for the provision of ecosystem Services. Environmental Management, 53, 783-799. doi:10.1007/s00267-014-0239-5.

Stanley, M. (2002). Alternatives to willows for riverbank protection: more weeds? Protect, (summer), 22-24.

Stokes, A, Norris, JE, van Beek, LPH, Bogaard, T, Cammeraat, E, Mickovski, SB, Jenner, A, Di lorio, A, \& Fourcaud, T. (2008). How vegetation reinforces soil on slopes. In JE Norris, A Stokes, SB Mickovski, E Cammeraat, R van Beek, BC Nicoll, \& A Achim (Eds.), Slope stability and erosion control: ecotechnological solutions (pp. 65-118). Dordrecht: Springer.

Stokes, A, Atger, C, Bengough, A, Fourcaud, T, \& Sidle, R. (2009). Desirable plant root traits for protecting natural and engineered slopes against landslides. Plant and Soil, 324, 1-30. doi:10.1007/s11104-009-0159-y.

Stokes, A, Douglas, GB, Fourcaud, T, Giadrossich, P, Gillies, C, Hubble, T, Kim, JH, Loades, KW, Mao, Z, Mclvor, IR, Mickovski, SB, Mitchell, S, Osman, N, Phillips, C, Poesen, J, Polster, D, Preti, F, Raymond, P, Rey, F, Schwarz, M, \& Walker, LR. (2014). Ecological mitigation of hillslope instability: ten key issues facing researchers and practitioners. Plant and Soil, 377, 1-23. doi:10.1007/s11104-014-2044-6.

Telewski, FW. (1995). Wind-induced physiological and developmental responses in trees. In MP Coutts \& J Grace (Eds.), Wind and Trees (pp. 237-263). Cambridge, UK: Cambridge University Press.

Trotter, C, Tate, K, Scott, N, Townsend, J, Wilde, H, Lambie, S, Marden, M, \& Pinkney, T. (2005). Afforestation/reforestation of New Zealand marginal pasture lands by indigenous shrublands: the potential for Kyoto forest sinks. Annals of Forest Science, 62, 865-871.

United States Department of Agriculture, Natural Resources Conservation Service (2014) http://plants.usda.gov/java/ Accessed 1 July 2015.

Van Kraayenood, CWS, \& Hathaway, RL. (1986). Plant Materials Handbook for Soil Conservation. Volume 2: Introduced Plants. Water and Soil Miscellaneous Publication No. 94. Wellington, New Zealand: Ministry of Works and Development.

Watson, A, \& O'Loughlin, C. (1990). Structural root morphology and biomass of three age-classes of Pinus radiata. New Zealand Journal of Forestry Science, 20(1), 97-110

Watson, AJ, \& Tombleson, JD. (2002). Toppling in juvenile pines: a comparison of the root system characteristics of direct-sown seedlings, and bare-root seedlings and cuttings. Plant and Soil, 239, 187-196.
Watson, AJ, \& Tombleson, JD. (2004). Toppling in young pines: temporal changes in root system characteristics of bare-rooted seedlings and cuttings. New Zealand Journal of Forestry Science, 34(1), 39-48.

Watson, AJ, Phillips, CJ, \& Marden, M. (1999). Root strength, growth, and rates of decay: root reinforcement changes of two tree species and their contribution to slope stability. Plant and Soil, 217, 39-47. doi:10.1023/ A: 1004682509514

\section{Submit your manuscript to a SpringerOpen ${ }^{\odot}$ journal and benefit from:}

- Convenient online submission

- Rigorous peer review

- Immediate publication on acceptance

- Open access: articles freely available online

- High visibility within the field

- Retaining the copyright to your article

Submit your next manuscript at $>$ springeropen.com 